\title{
Temporal distribution of ichthyoplankton in the Ivinhema River (Mato Grosso do Sul State/ Brazil): Influence of environmental variables
}

\author{
David Augusto Reynalte-Tataje ${ }^{1,2}$, Keshiyu Nakatani ${ }^{2,3 \dagger}$, Rodrigo Fernandes ${ }^{2}$, \\ Angelo Antônio Agostinho ${ }^{2,3}$ and Andréa Bialetzki ${ }^{2,3}$
}

Information on ichthyoplankton is an important tool in determining reproduction periods that - if associated to environmental variables - allows for inferences about the factors that regulate their intensity, beginning, and ending. In this context, this study aims to establish (i) ichthyoplankton composition; (ii) temporal variations in the overall density of eggs and larvae and among the most important taxa; and (iii) the influence of some abiotic and biotic variables on these organisms' abundance. Ichthyoplankton sampling was undertaken during the period between April 2005 and March 2006 at the Ivinhema River, upper Paraná River basin (MS/Brazil). Differences in the ichthyoplankton's temporal variation were evaluated using unifactorial ANOVAs. Principal Component Analysis and Pearson's correlation were used for the relationships between eggs and larvae densities and environmental variables. A total of 3,341 eggs and 2,896 larvae were captured during the period studied, and most of them were medium-sized and large species that carried out some type of reproductive migration. The highest densities of eggs and larvae occurred during the months of spring and summer, except for those of Bryconamericus stramineus, which was most abundant during the winter. The density of ichthyoplankton was most positively correlated with the water's outflow and temperature. However, Plagioscion squamosissimus was positively related to the increase in $\mathrm{pH}$ and in zooplanktonic organisms, while $B$. stramineus was inversely correlated with water outflow and temperature. The study concludes that spawning is most intense in the spring and summer, especially between November and January, and is related to the greatest values of water temperature and outflow. Nevertheless, the response and reproductive intensity in relation to the environmental variables vary according to the species.

As informações sobre o ictioplâncton são ferramentas importantes para a determinação do período de reprodução que, se associado às variáveis ambientais, permitem inferências sobre os fatores que regulam sua intensidade, início e término. Nesse contexto, o presente estudo visa determinar: (i) a composição do ictioplâncton; (ii) as variações temporais na densidade de ovos, larvas e dos táxons mais importantes; e (iii) a influência de algumas variáveis abióticas e bióticas sobre a abundância destes organismos. As coletas de ictioplâncton foram realizadas no período de abril de 2005 a março de 2006, no rio Ivinhema, bacia do alto rio Paraná (MS/Brasil). Diferenças nas variações temporais do ictioplâncton foram avaliadas por ANOVAs unifatoriais. Análises de Componentes Principais e correlação de Pearson foram utilizadas para avaliar as relações entre densidade de ovos e larvas e as variáveis ambientais. Durante o período estudado, foram capturados 3.341 ovos e 2.896 larvas, sendo que a maior parte foi de espécies de médio e grande porte e que realizam algum tipo de migração reprodutiva. Ovos e larvas apresentaram suas maiores densidades nos meses de primavera e verão, exceto Bryconamericus stramineus que foi mais abundante no inverno. A densidade de ictioplâncton esteve mais correlacionada positivamente com a vazão e a temperatura da água. Contudo, Plagioscion squamosissimus apresentou relação positiva com o aumento do $\mathrm{pH}$ e dos organismos zooplanctônicos, enquanto $B$. stramineus apresentou correlação inversa com a vazão e temperatura da água. Conclui-se que as desovas são mais intensas na primavera-verão, principalmente entre novembro e janeiro, e estão relacionadas aos maiores valores de temperatura e vazão da água. Entretanto, a resposta e a intensidade reprodutiva às variáveis ambientais variam de acordo a espécie.

Key words: Bryconamericus stramineus, Fish, Floodplain, Larvae, Plagioscion squamosissimus.

\footnotetext{
$\dagger$ In memorian.

${ }^{1}$ Laboratório de Biologia e Cultivo de Peixes de Água Doce (LAPAD) - Universidade Federal de Santa Catarina (UFSC). Rodovia SC 406, Km 3, 3532, 88066-000 Armação, Florianópolis, SC, Brazil. reynalted@hotmail.com

${ }^{2}$ Pós-Graduação em Ecologia de Ambientes Aquáticos Continentais - Universidade Estadual de Maringá (UEM).

${ }^{3}$ Núcleo de Pesquisas em Limnologia, Ictiologia e Aquicultura (Nupélia). Av. Colombo, 5790, Bloco G-90, 87020-900 Maringá, PR, Brazil.
} 


\section{Introduction}

The period of reproduction for most freshwater fish species is seasonal and related to favorable conditions that maximize fecundation and offspring development (Agostinho et al., 2004). Many species carry out migrations during the reproductive period and seek appropriate areas to release their gametes and allow them to be fertilized. Fertilized eggs are then carried away by the current to areas that favor their development (Vazzoler, 1996). However, the reproductive period and amplitude of the fish community varies between different drainage basins and is largely dependent on local environmental variables (Humphries et al., 1999; Winemiller, 2004).

Studies carried out at the Prata basin have shown that, in general, fish's reproduction occurs from October to March (Baumgartner et al., 1997, 2004; Bialetzki et al., 2005; ReynalteTataje et al., 2008; Tondato et al., 2010) and the main environmental variables responsible for the ichthyoplanktonic community's distribution are: photoperiod (Vazzoler et al., 1997), temperature (Oldani, 1990; Reynalte-Tataje et al., 2008), outflow and/or increase in water volume (Quiroz \& Cutch, 1989; Agostinho et al., 2004), and increases in food availability (Bonetto et al., 1969). Despite this, the real importance of each of these variables for reproduction is still not totally clear.

Knowledge of ichthyoplankton's temporal distribution throughout one annual cycle can be a valuable tool to establish fishing management actions, such as the defeso period (a closed season when fishing a given species is prohibited because of reproduction) (Stanford et al., 1996; King et al., 2003), helping to protect vulnerable and threatened species (Reynalte-Tataje et al., 2008). Some studies carried out in the Ivinhema River suggest that this is one of the main environments for fish reproduction in the upper Paraná River floodplain (Baumgartner et al., 1997; Nakatani et al., 1997; Sanches et al., 2006); however, studies that confirm reproductive activity in the region and that help to understand the region's annual reproduction variability are still scarce. Thus, this study sought to contribute to the knowledge of the reproductive process of the Ivinhema River's fish and aimed to evaluate (i) ichthyoplankton composition; (ii) the temporal variation of eggs, larvae, and the most important taxa found in the ichthyoplankton; and (iii) the influence of environmental variables (biotic and abiotic) on these organisms' abundance throughout one annual cycle.

\section{Material and Methods}

\section{Study area}

The Ivinhema River is located on the right bank of the Paraná River (Mato Grosso do Sul State, Brazil). It stretches over approximately $230 \mathrm{~km}$, but the upper and middle sections run in the north-south direction, while the inferior portion runs parallel to the Paraná River (northeast-southwest direction) until it converges with this river. The region of the Ivinhema River is one of the few remaining segments with lotic characteristics in the upper Paraná River's floodplain, as the rest of the basin is under strong influence of damming. Preliminary studies have demonstrated that rheophilic species are using these environments as nursery areas and reproduction sites (Nakatani et al., 1997; Baumgartner et al., 2004; Gogola et al., 2010) probably due to the river's characteristics, such as its still natural hydrodinamics, and the fact that it is located in a protected area where there is still marginal vegetation and many floodplains (Souza Filho \& Stevaux, 1997).

The studied area (Fig. 1) is located in the lower portion of Ivinhema River (22 $\left.47^{\prime} 59^{\prime \prime} \mathrm{S} 53^{\circ} 32^{\prime} 21^{\prime \prime} \mathrm{W}\right)$ and is characterized by an average speed of $0.85 \mathrm{~m} / \mathrm{s}$ and by the transportation of a large amount of sediments (Souza Filho \& Stevaux, 1997).

\section{Sampling}

Samplings were carried out between April 2005 and March 2006 during the night at 4-h intervals (20:00, 24:00, and 04:00 h). At each time, triplicate samples were collected using three conical-cylindrical plankton nets $(0.5 \mathrm{~mm}$ mesh $)$ tied to a cable stretched between the margins of the river, so that each net could be placed in each margin and in the middle of the river.

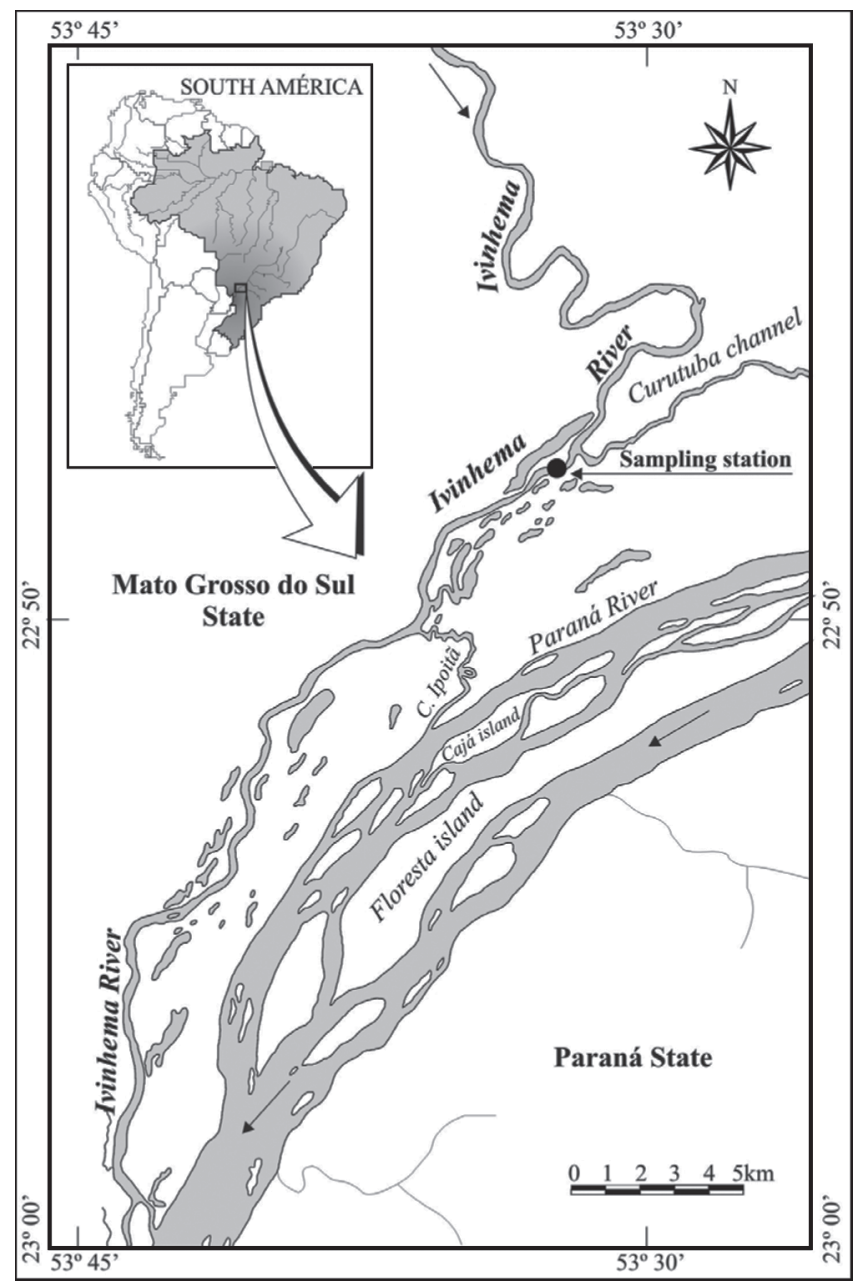

Fig. 1. Location of the sampling station. 
The equipments were used in the water during $15 \mathrm{~min}$ and a flow meter was fixed to the mouth of each net to determine the volume of water filtered. Samples were fixed in a buffered $4 \%$ formalin solution. In the laboratory samples were sorted and the larvae were separated from the rest of the material.

Larvae were identified to the lowest taxonomic level possible, according to Nakatani et al. (2001). Only the larvae identified at least to the genus level were considered in the analysis.

Zooplankton was collected, simultaneously to the ichthyoplankton samplings, using a plankton net with a $70 \mu \mathrm{m}$ mesh, through which $200 \mathrm{~L}$ of water from the subsurface was filtered. The material collected was fixed in diluted to $4 \%$ formaldehyde buffered with calcium carbonate. In the laboratory the zooplanktonic organisms were removed and quantified, and the results were presented as organisms $/ \mathrm{m}^{3}$.

Some of the water's physical and chemical variables were also measured simultaneously to the plankton collections, such as temperature $\left({ }^{\circ} \mathrm{C}\right)$, dissolved oxygen $(\mathrm{mg} / \mathrm{l}), \mathrm{pH}$, and electrical conductivity $(\mu \mathrm{S} / \mathrm{cm})$. Water transparency data was recorded during daytime. Values of precipitation and outflow, however, were provided by Itaipu Binacional as obtained from the Ivinhema hydrometeorological station.

\section{Data analysis}

In order to identify most abundant species, the following values were used during the period studied: average density, the samples' taxa occurrence frequency, and the biological value index (BVI). According to Sanders (1960), the BVI works by balancing two important numerical attributes related to species composition in a given community: abundance and spatial-temporal constancy, which avoids ordering species based on specific data that is dominant but not very representative.

The unifactorial analysis of variance (ANOVA one-way) was applied to evaluate differences between the monthly abundance averages $\left(\log _{10} x+1\right.$; dependent variable) of eggs and larvae; the independent factor were the months of the year. The protected ANOVA protocol was applied to evaluate the temporal variation of the ten most abundant taxa using the BVI (Hicks, 1993). In this protocol, a multivariate analysis of variance (MANOVA) is applied initially; if there is significance, unifactorial ANOVA's are applied for all of the species. This approach is recommended because random differences can be found (type I error) when several tests are used. When the ANOVA's results were significant, Tukey's test was applied a posteriori to evaluate differences between the months.

Pearson correlations were used to evaluate the influence of environmental variables (biotic and abiotic) with egg and larva abundance for the main taxa. Earlier, a principal components analysis (PCA) was applied with the aim of reducing environmental variables' dimensionality. All of the variables (except $\mathrm{pH}$ ) were previously log-transformed $\left(\log _{10} \mathrm{x}+1\right)$ to linearize the inter-variable relationships (Peters, 1986). Only the axes with eingevalues higher than the randomly generated values were retained for interpretation (Broken-Stick criterion; Jackson, 1993). Abiotic factors with eigenvectors (correlations) larger than 0.40 were considered biologically important (Hair et al., 1984).

\section{Results}

\section{Ichthyoplankton taxonomic composition}

A total of 3,341 eggs and 2,896 larvae were captured during the period studied. From all of the larvae captured, 53.6\% belonged to order Siluriformes and $38.2 \%$ to order Characiformes. Larvae from orders Gymnotiformes and Perciformes and unidentified specimens added up to $8.2 \%$ of the total. Three groups were identified to the genus level and 22 to a specific level, distributed into 15 families. Among the families identified, those with the greatest number of taxa were the Pimelodidae (7) and the Characidae (3). The remaining families had only one of two taxa each. The species with the greatest temporal amplitude were Plagioscion squamosissimus and Auchenipterus osteomystax (occurred in seven months each), followed by Bryconamericus stramineus (five months). Only these three species were found in Ivinhema River during the autumn and winter (Table 1).

The three measurements used to evaluate the most representative taxa of Ivinhema River had different results. According the average density, the two main species were Prochilodus lineatus and Cetopsis gobioides, while the most frequent were Pseudoplatystoma corruscans and $B$. stramineus. Conversely, the second BVI showed that the species with the most constant abundance over time were $P$. squamosissimus and A. osteomystax (Table 1).

\section{Seasonally variation of eggs and larvae and of the main taxa}

The ANOVA showed differences in the temporal distribution of eggs $(F=6.17 ; p<0.05)$ and larvae $(F=18.58$; $\mathrm{p}<0.05)$. In general, the eggs were captured between the months of October and February and in August, and the highest densities were recorded between October and December (Tukey; $\mathrm{P}<0.05$ ) (Fig. 2A). Larvae were present in all of the months, yet the highest densities were found between November and January (Tukey; $\mathrm{P}<0.05$ ) (Fig. 2B).

The average densities of the most important taxa of the Ivinhema River are presented in Fig. 3. The multivariate analysis of variance (MANOVA) applied to these densities (with the month as the factor) was significant (Wilks' W test: months $=5.68 ; \mathrm{P}<0.001)$, indicating the appropriateness of the ANOVA's for each taxon separately.

The analysis of variance was significant for six of the ten species evaluated (according to the BVI) (Table 2). For $B$. stramineus (ANOVA: $\mathrm{df}=11 ; \mathrm{F}=10.482 ; \mathrm{p}=0.000$; Table 2 ), the greatest densities of larva were obtained during the month of August (Tukey; $\mathrm{P}<0.05$ ); this was the only species which highest densities were outside of the spring-summer months. Conversely, the larva densities of $P$. lineatus (ANOVA: $\mathrm{df}=11$; $\mathrm{F}=8.342 ; \mathrm{p}=0.000 ;$ Table 2 ) and $C$. gobioides (ANOVA: $\mathrm{df}=11 ; \mathrm{F}=4.321 ; \mathrm{p}=0.000 ;$ Table 2 ) were significantly 
Table 1. Composition and ranking of the biological value index (BVI), average monthly and yearly density (individuals $/ 10 \mathrm{~m}^{3}$ ), and annual occurrence frequency (OF) of the fish larva taxa verified between April 2005 and March 2006 at the Ivinhema River (Mato Grosso do Sul State, Brazil).

\begin{tabular}{|c|c|c|c|c|c|c|c|c|c|c|c|c|c|c|c|}
\hline Taxon & Apr 05 & May & Jun & Jul & Aug & Sep & Oct & Nov & Dec & Jan 06 & Feb & Mar & BVI & Density & $\mathrm{OF}$ \\
\hline Plagioscion squamosissimus & 0.05 & 0.10 & 0.16 & 0.13 & & & 0.02 & 0.01 & 0.30 & & & & 1 & 0.06 & 13.9 \\
\hline Auchenipterus osteomystax & & & 0.06 & & & 0.15 & 0.08 & 0.08 & 0.01 & 0.02 & & 0.01 & 2 & 0.03 & 14.8 \\
\hline Bryconamericus stramineus & & & & & 0.84 & 0.12 & 0.05 & 0.01 & & 0.05 & & & 3 & 0.09 & 18.5 \\
\hline Pseudoplatystoma corruscans & & & & & & & & 0.47 & 0.06 & 1.31 & 0.04 & & 4 & 0.16 & 20.5 \\
\hline Sorubim lima & & & & & & & & 0.16 & 0.05 & 0.01 & 0.04 & & 5 & 0.02 & 9.3 \\
\hline Cetopsis gobioides & & & & & & & & 0.03 & 3.17 & & 0.04 & & 6 & 0.27 & 8.3 \\
\hline Prochilodus lineatus & & & & & & & 0.01 & 0.02 & 8.07 & & & & 7 & 0.68 & 8.3 \\
\hline Iheringichthys labrosus & & & & & & & 0.02 & 0.02 & 0.01 & 0.04 & & & 8 & 0.01 & 6.5 \\
\hline Rhaphiodon vulpinus & & & & & & & 0.02 & 0.44 & 0.11 & & & & 9 & 0.05 & 15.7 \\
\hline Brycon orbignyanus & & & & & & & 0.10 & 0.01 & & & & & 10 & 0.01 & 3.7 \\
\hline Pimelodus spp. & & & & & & & 0.21 & & 0.01 & & & & 11 & $>0.01$ & 4.6 \\
\hline Gymnotus spp. & & & & & & & & 0.01 & 0.01 & 0.01 & & & 12 & $>0.01$ & 3.7 \\
\hline Hoplerythrinus unitaeniatus & & & & & & & & 0.01 & 0.07 & & & & 13 & 0.01 & 3.7 \\
\hline Hypophthalmus edentatus & & & & & & & & & & 0.02 & & & 14 & $>0.01$ & 0.9 \\
\hline Loricariichthys platymetopon & & & & & & & & & & & 0.01 & & 15 & $>0.01$ & 0.9 \\
\hline Pinirampus pirinampu & & & & & & & & & 0.08 & & & & 16 & 0.01 & 2.8 \\
\hline Pterygoplichthys ambrosettii & & & & & & & & & & 0.01 & & & 17 & $>0.01$ & 1.9 \\
\hline Rhamdia quelen & & & & & & & 0.01 & & & & & & 18 & $>0.01$ & 0.9 \\
\hline Leporinus spp. & & & & & & & & 0.01 & & & & & 19 & $>0.01$ & 0.9 \\
\hline Salminus brasiliensis & & & & & & & & & 0.05 & & & & 20 & $>0.01$ & 2.8 \\
\hline Hoplosternum littorale & & & & & & & & & 0.03 & & & & 21 & $>0.01$ & 2.8 \\
\hline Zungaro zungaro & & & & & & & & & 0.02 & & & & 22 & $>0.01$ & 0.9 \\
\hline Callichthys callichthys & & & & & & & & & 0.01 & & & & 23 & $>0.01$ & 1.9 \\
\hline Amaralia sp. & & & & & & & & 0.01 & & & & & 24 & $>0.01$ & 0.9 \\
\hline Hoplias aff. malabaricus & & & & & & & & & 0.01 & & & & 25 & $>0.01$ & 0.9 \\
\hline
\end{tabular}

higher in December (Tukey; $\mathrm{P}<0.05$ ); the larva densities of Rhaphiodon vulpinus (ANOVA: $\mathrm{df}=11 ; \mathrm{F}=11.941 ; \mathrm{p}=0.000$; Table 2) were higher in November and December (Tukey; $\mathrm{P}<0.05$ ); of $P$. corruscans (ANOVA: $\mathrm{df}=11 ; \mathrm{F}=2.954 ; \mathrm{p}=$ 0.002 ; Table 2) in January (Tukey; $\mathrm{P}<0.05$ ); and of Sorubim lima (ANOVA: $\mathrm{df}=11 ; \mathrm{F}=3.138 ; \mathrm{p}=0.001$; Table 2) in November (Tukey; $\mathrm{P}<0.05$ ).

\section{Influence of the environmental variables on the most important taxa's eggs and larvae}

The environmental variables showed a clear seasonal variation. The greatest values of water temperature and outflow were recorded between October and March (Fig. 4A and 4B). High concentrations of dissolved oxygen were verified between the months of May and July, while low concentrations were found in November and December (Fig. 4B). The highest values of $\mathrm{pH}$ were for May and July and the highest conductivity was recorded in February (Fig. 4C). Precipitation oscillated a lot throughout the year (Fig. 4A). The highest densities of zooplanktonic organisms occurred during the month of May, and high densities also occurred in April, June, August, and December (Fig. 4D).

The PCA revealed that only axis 1 and 2 presented eingevalues that were higher than those generated randomly and were retained for interpretation. Together these two axes explained $54.78 \%$ of data variability. The first axis (PC1) had an eingevalue of 3.29 and explained $36.58 \%$ of the variability. In this axis, the variables that had the most positive contribution were dissolved oxygen and water transparency, while water outflow and temperature contributed negatively. The second axis (PC2) had an eingevalue of 1.64 and explained
$18.20 \%$ of data variability. The $\mathrm{pH}$ and the zooplanktonic organisms were the variables that had the most positive contribution for PC2 (Table 3).

Egg and larva density was positively correlated to increases in water temperature and outflow and negatively correlated with water transparency. Egg density was also inversely correlated to the increase in dissolved oxygen and $\mathrm{pH}$. Table 4 presents the correlation between the environmental variables considered important by the PCA and the density of the most abundant taxa of the period.

\section{Discussion}

The larval assemblage found in the Ivinhema River mainly comprised medium and large Siluriformes and Characiformes. The high diversity of species of these two orders in neotropical environments has been observed by several authors (Lowe-McConnell, 1987; Agostinho et al., 1997). Of the 22 species identified (a little over 91 of the total species that occur in the Ivinhema River sub-basin; Agostinho et al., 1997), eight are considered migratory, i.e., they are total spawners, with short reproductive periods, small eggs, and absence of parental care, besides that they move great distances during the reproductive period (Agostinho et al., 2004; Suzuki et al., 2005). This information indicates the presence of reproductive activity of migratory fish and emphasize the importance of this river on the maintenance of fisheries stocks, as well as on the necessity of adopting management actions to preserve this tributary.

The species with the highest average density of larvae in the Ivinhema River, P. lineatus and C. gobioides, were 

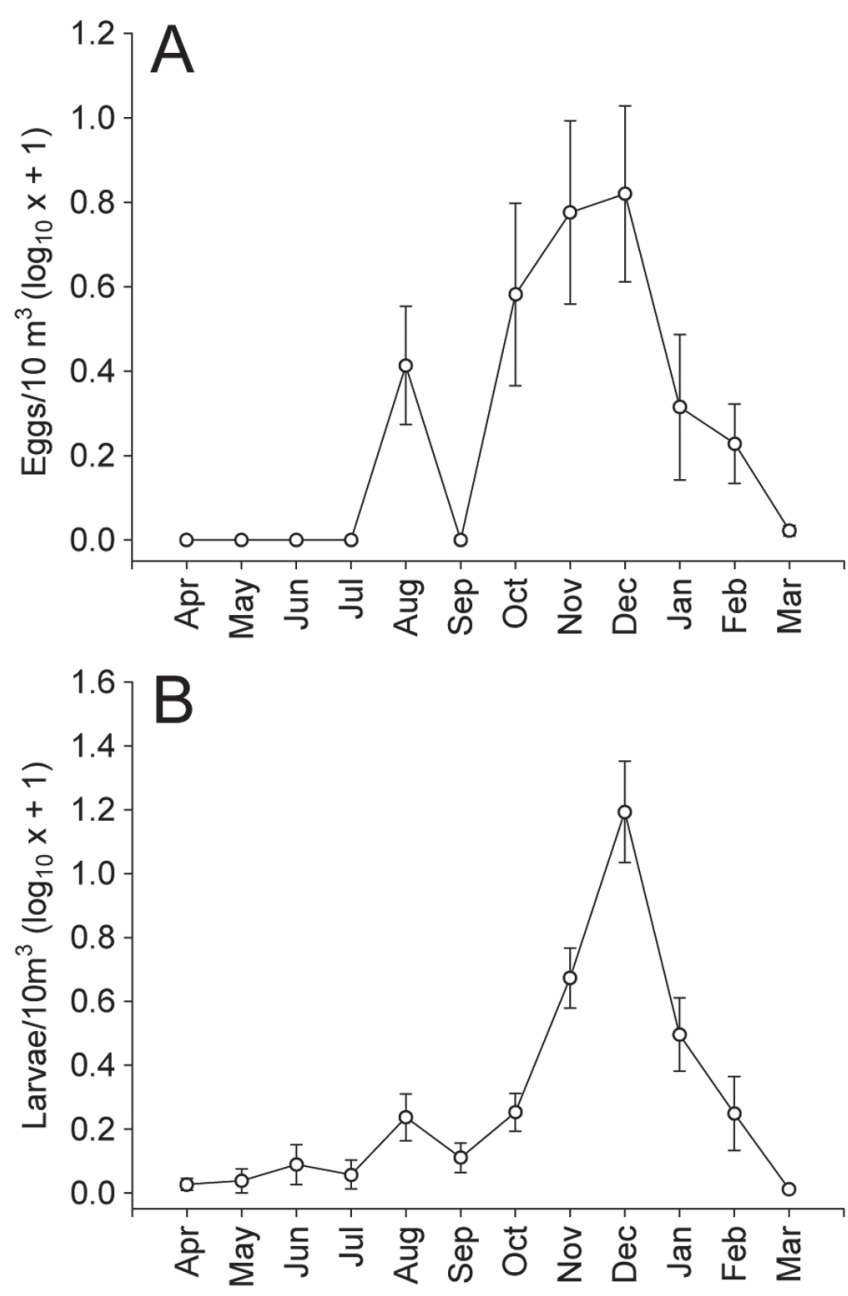

Fig. 2. Fish egg (A) and larva (B) abundance in the Ivinhema River (Mato Grosso do Sul State, Brazil) for the period between April 2005 and March 2006 (circles = average value; bars = standard error).

coincidently highly abundant during a single month (December). This indicates that one factor must promote massive spawning for these two species - involving a great number of individuals in a short period of time. Conversely, occurrence frequency privileged species that were constant throughout the samplings, $P$. corruscans and B. stramineus. Despite their frequency, their abundance was lower than that of $P$. lineatus and $C$. gobioides, which suggests that their occurrence in the samples was generally low, regardless of constancy. The spawning of small groups of a certain species at different moments may enlarge the possibility that some larvae or juveniles find adequate environmental conditions to grow, and may also reduce intrinsic resource competition between individuals of the same species.

The BVI valued the species that were most constant in time. One species' spawning during most of the year indicates great reproductive flexibility and reduced influence of environmental variables on the reproductive strategy. Thus, P. squamosissimus and A. osteomystax had the longest reproductive period. Their larvae were captured in more than half of the year, but $A$. osteomystax was found in the months of spring and summer and also in autumn, while $P$. squamosissimus was found in spring, autumn, and winter. The absence of this species' larvae in the summer is surprising, as this species greatest reproductive activity occurs during this season and this event is associated to higher water temperatures (Bialetzki et al., 2004). We hypothesize that the December flood negatively influenced this species' reproduction, as a study carried out during four reproductive periods in several environments of the Ivinhema River sub-basin showed a negative correlation between the presence of ichthyoplanktonic organisms and outflow (Reynalte-Tataje et al., unpublished data). In general, the BVI and the frequency of occurrence favored species which were more constant temporally, such as the opportunistic species with batch spawning; on the other hand, the average was an index which favored the presence of migratory species which are seasonal and with total spawning and a high number of eggs and larvae in a short period of time.

Despite $P$. lineatus and $P$. corruscans being migratory species and total spawners, both distinguished themselves in relation to the distribution of the abundance of larvae during the period studied, which suggests that they have distinct reproductive strategies and respond differently to changes in environmental variables. Prochilodus lineatus responded in a specific and intense manner to the environmental stimuli present in the month of December (probably due to the flood that occurred during that month), while $P$. corruscans had more reproductive flexibility in relation to these stimuli (and its larvae were found between the months of November and February).

Several studies carried out in the Prata basin have shown that the drift of ichthyoplanktonic organisms is highly seasonal, with the greatest densities in the spring and summer (Oldani, 1990; Bialetzki et al., 2005; Reynalte-Tataje et al., 2008). The greatest reproductive activity of the upper Paraná River floodplain's fish in the months of spring has been reported by Vazzoler (1996), who also indicates the period of NovemberFebruary as that of the highest reproductive intensity.

Despite the similar number of eggs and larvae, these organisms have different distributions. Thus, while the larvae were found throughout the year, eggs were only observed between August and March. The absence of eggs during the samplings carried out in the autumn and in part of the winter may be related mainly to the inefficiency of the sampling method used to capture pelagic (found in the lentic region of the Ivinhema River sub-basin) and marginal eggs, as the equipment installed in the river collects mainly eggs that develop in lotic environments. In this study, only $A$. osteomystax and P. squamosissimus larvae were found during this period. The first species' spawning occurs in the marginal region, where the adhesive eggs (personal observation) become unavailable for the sampling equipment. The latter's spawning happens in the lentic environments found in the floodplain (Bialetzki et al., 2004). 

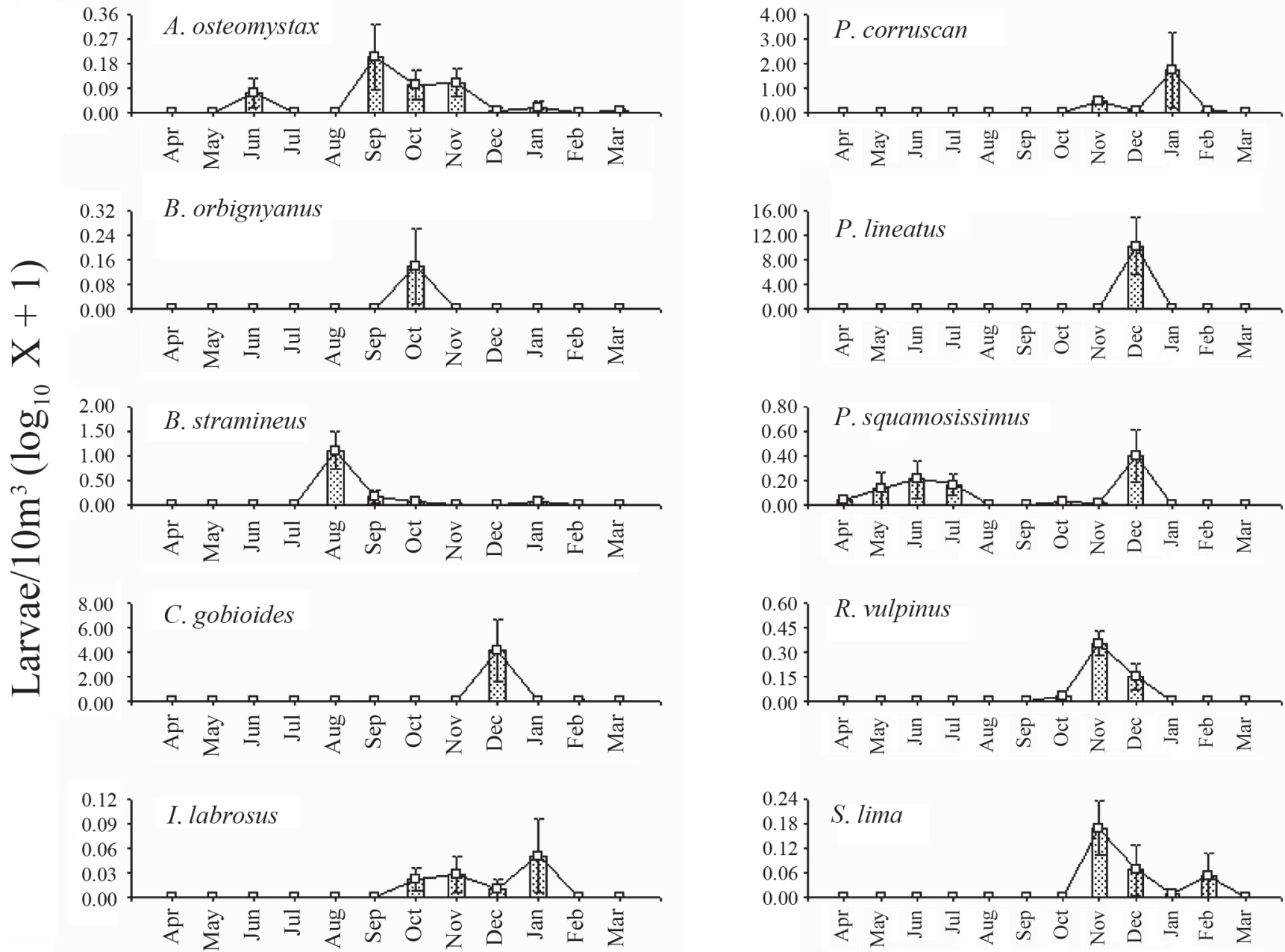

Fig. 3. Average fish larva abundance of the ten most important taxa captured in the Ivinhema River (Mato Grosso do Sul State, Brazil) during the period between April 2005 and March 2006.

The environmental variables may indirectly affect the fish community by influencing physiological and behavioral responses, and directly by influencing species' distribution and abundance patterns (Vazzoler et al., 1997; Reynalte-Tataje et al., 2008). Variables such as photoperiod, the river's hydrodynamics and water temperature are essential to fish occurrence, density, and growth in their first life stages (Vlaming, 1972; Humphries et al., 1999). In the environment studied, egg and larval abundance was markedly seasonal, and matched the highest values of water outflow and temperature and the lowest values of dissolved oxygen, $\mathrm{pH}$, and transparency. In general, the highest abundances of eggs and larvae at the Ivinhema River were observed during the rising waters and flood when temperature and water level were highest, and $\mathrm{DO}, \mathrm{pH}$ and transparency were lowest. Similar results were obtained to other environments at the upper Paraná River (Baumgartner et al., 2004; Baumgartner et al., 2008; Fernandes et al., 2009). During this period, the highest larval densities of migratory species such as Sorubim lima, Pseudoplatystoma corruscans, Prochilodus lineatus, and Rhapiodum vulpinus were found.
In the Prata basin there are drainage basins such as those of the Paraná in which floods coincide with high temperatures (Oldani, 1990; Vazzoler et al., 997); however, there are also regions such as the upper Uruguay River in which the floods happen when the water's temperature is still low (Reynalte-Tataje et al., 2008).

Table 2. Unifactorial ANOVA applied to the fish larva density of the ten most important taxa of the Ivinhema River (Mato Grosso do Sul State, Brazil), considering the month as the factor. Values in bold type indicate differences.

\begin{tabular}{lcc}
\hline \multirow{2}{*}{ Species } & \multicolumn{2}{c}{ Factor: Month (DF $=11)$} \\
\cline { 2 - 3 } & $\mathrm{F}$ & $\mathrm{P}$ \\
\hline Auchenipterus osteomystax & 2.993 & 0.054 \\
Brycon orbignyanus & 1.481 & 0.153 \\
Bryconamericus stramineus & 10.482 & $\mathbf{0 . 0 0 0}$ \\
Cetopsis gobioides & 4.321 & $\mathbf{0 . 0 0 0}$ \\
Iheringichthys labrosus & 1.803 & 0.087 \\
Plagioscion squamosissimus & 1.933 & 0.053 \\
Prochilodus lineatus & 8.342 & $\mathbf{0 . 0 0 0}$ \\
Pseudoplatystoma corruscans & 2.954 & $\mathbf{0 . 0 0 2}$ \\
Rhaphiodon vulpinus & 11.941 & $\mathbf{0 . 0 0 0}$ \\
Sorubim lima & 3.138 & $\mathbf{0 . 0 0 1}$ \\
\hline
\end{tabular}



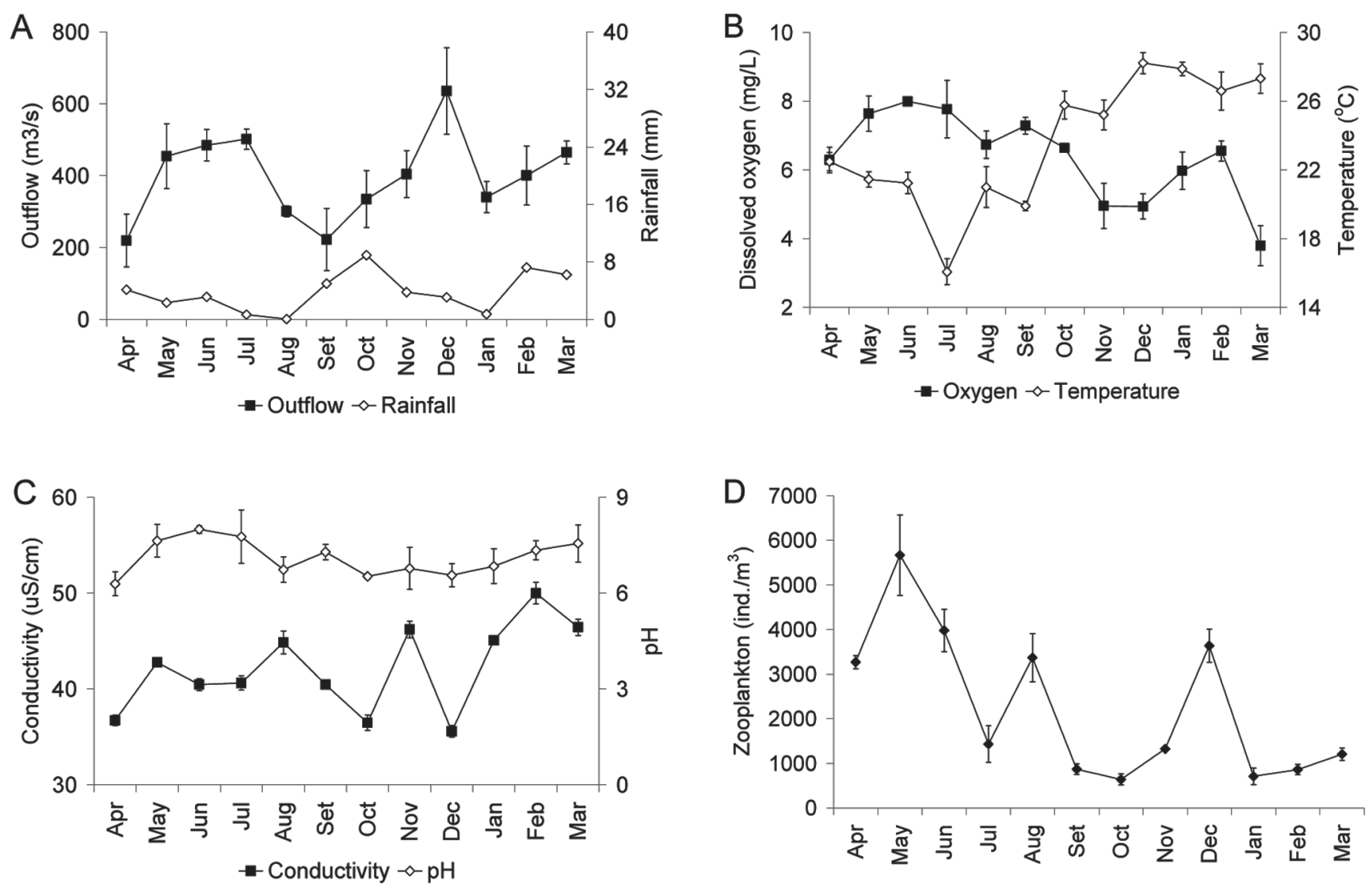

Fig. 4. Average values and standard error of the environmental variables obtained at the Ivinhema River (Mato Grosso do Sul State, Brazil) during the period between April 2005 and March 2006. A. Water outflow and rainfall; B. Dissolved oxygen and water temperature; $\mathbf{C}$. Electrical conductivity and $\mathrm{pH}$; and $\mathbf{D}$. Total zooplankton.

In the first case, adult fish spawning and larva development could benefit from the floods' effects, which promote an increase in the planktonic and benthic communities due to the insertion of nutrients (Arumugam \& Geddes, 1987) and the increase in space, and make more microhabitats available for growth and protection. Nevertheless, because the three main variables that regulate fish's life cycle (photoperiod, floods, and water temperature) (Vlaming, 1972; Ward \& Stanford, 1989; Munro, 1990) show a trend during the peak of reproductive activity in the Ivinhema River, it is hard to distinguish which is the chief reproduction variable for most species of the region.

There is a perception that for neotropical species variations in water level and outflow synchronize biological events such as gonad maturation, migration, and spawning (Harris \& Gehrke, 1994; Humphries et al., 1999). For some researchers, however, spawning is independent from increases in flow. Nonetheless, the benefits of flooding for reproductive success would be indirect due to the advantages that larvae and juveniles would have with the introduction of nutrients and the increase in the number of refuges (Humphries et al., 1999). In fish farms, the gonads of several native species of the Prata basin mature during the spring and summer, regardless of changes in outflow and water level in their area of cultivation (Reynalte-Tataje et al., 2008); however, few species are able to find stimuli to spawn in confined environments. In the natural environment, Vazzoler et al. (1997) verified a positive correlation between reproductive intensity and photoperiod and water temperature, and no monotonic correlation was found with water level.

Table 3. Scores of the Principal Component Analysis base on environmental (biotic and abiotic) variables of the Ivinhema River (Mato Grosso do Sul State, Brazil) during the period from April 2005 to March 2006. Values in bold type are significant (Hair et al., 1984).

\begin{tabular}{lcc}
\hline Variables & PC1 & PC2 \\
\hline Outflow & $\mathbf{- 0 . 5 1}$ & 0.27 \\
Precipitation & -0.27 & 0.06 \\
Temperature & $\mathbf{- 0 . 4 6}$ & -0.15 \\
Dissolved oxygen & $\mathbf{0 . 4 2}$ & 0.07 \\
pH & 0.19 & $\mathbf{0 . 6 0}$ \\
Electrical conductivity & -0.07 & 0.16 \\
Transparency & $\mathbf{0 . 4 1}$ & 0.09 \\
Zooplankton & 0.18 & $\mathbf{0 . 4 0}$ \\
$\quad$ Eingevalue & 3.29 & 1.64 \\
$\quad$ Percentage of explanation $(\%)$ & 36.58 & 18.20 \\
\hline
\end{tabular}


Table 4. Pearson's correlation between the environmental variables (biotic and abiotic) and egg and larva densities of the most abundant taxa in the Ivinhema River (Mato Grosso do Sul State, Brazil) during the period from April 2005 and March 2006. Bold type refers to $\mathrm{P}<0.05$.

\begin{tabular}{|c|c|c|c|c|c|c|}
\hline Taxa & Outflow $\left(\mathrm{m}^{3} / \mathrm{s}\right)$ & Temperature $\left({ }^{\circ} \mathrm{C}\right)$ & Dissolved oxygen (mg/l) & $\mathrm{pH}$ & Transparency $(\mathrm{cm})$ & Zooplankton (ind. $/ \mathrm{m}^{3}$ ) \\
\hline$\overline{\text { Ovos }}$ & 0.33 & 0.50 & -0.49 & -0.56 & -0.55 & -0.11 \\
\hline Larvas & 0.59 & 0.49 & -0.41 & -0.40 & -0.49 & 0.16 \\
\hline A. osteomystax & -0.38 & -0.17 & 0.14 & -0.02 & -0.01 & -0.37 \\
\hline B. orbignyanus & -0.16 & 0.17 & 0.06 & -0.33 & -0.39 & -0.31 \\
\hline B. stramineus & -0.64 & -0.08 & 0.11 & -0.23 & 0.54 & 0.14 \\
\hline C. gobioides & 0.62 & 0.38 & -0.36 & -0.31 & -0.38 & 0.26 \\
\hline I. labrosus & -0.06 & 0.51 & -0.30 & -0.41 & -0.75 & -0.41 \\
\hline P. squamosissimus & 0.76 & -0.07 & 0.08 & 0.59 & -0.23 & 0.55 \\
\hline$P$. lineatus & 0.62 & 0.38 & -0.35 & -0.31 & -0.39 & 0.26 \\
\hline P. corruscans & -0.11 & 0.40 & -0.23 & -0.22 & -0.45 & -0.34 \\
\hline R. vulpinus & 0.17 & 0.22 & -0.43 & -0.28 & -0.25 & -0.12 \\
\hline$\underline{\text { S. lima }}$ & 0.19 & 0.30 & -0.44 & -0.25 & -0.19 & -0.17 \\
\hline
\end{tabular}

Nevertheless, despite the general trends that exist for fish communities, the differences in reproductive strategies found inside the same community allow the populations to respond differently to environmental variables from region to region. When the larva abundance of the ten main species is correlated with the environmental variables, it is verified that $C$. gobioides and $P$. lineatus present greater abundance with the increase in water outflow. The presence of eggs and larvae of $C$. gobioides in areas under the influence of strong currents during the period of high outflow was observed by ReynalteTataje \& Zaniboni-Filho (2008) in the upper Uruguay River, where this species spawns in the river groove, especially in the months of spring. The greatest reproductive activity of $P$. lineatus when the values of outflow and water level increase has been recorded by several authors (Agostinho \& Zalewski, 1995; Agostinho et al., 2004), who consider that during the great floods the detritivore species benefit from the expansion in water that allows the vegetation to inundate and brings in a considerable amount of organic matter.

Brycomericus stramineus and $P$. squamosissimus had the greatest number of larvae in other environmental conditions. The larvae of $B$. stramineus were especially abundant in the month of August, when outflow was reduced and temperature was low. The increase in the number of $B$. stramineus larvae in these conditions was also observed by Bialetzki et al. (2005) in another environment of the upper Paraná River floodplain. Conversely, in the upper Uruguay River, this species' larvae have been found mainly in the months of summer, which match the region's dry period (Reynalte-Tataje et al., 2008). The larvae of $P$. squamosissimus, on the other hand, were more abundant in conditions of high $\mathrm{pH}$ and outflow, and more zooplanktonic organisms. The relationship between these larvae and the $\mathrm{pH}$ was verified by Baumgartner et al. (1997), who observed a direct correlation between this species' abundance and the $\mathrm{pH}$; they discuss that although the mechanism of the $\mathrm{pH}$ that affects the reproductive process is unknown, this variable must somehow act upon this species and induce spawning. Conversely, its high correlation with the zooplanktonic organisms and Ivinhema River's outflow is related to flooding in the plain. In this period the organisms present and abundant in the lagoons, such $P$. squamosissimus and the zooplankton enter the river and increase the channel's population while diluting it in the lentic environments.

Finally, as mentioned previously, the increase in abundance of the zooplanktonic organisms in the Ivinhema River throughout the periods of great outflow is probably also a result of the similarity between the different environments during flooding; however, this increase may also be a consequence of the availability of nutrients in the river's groove (Thomaz et al., 2007). Studies carried out in other basins have recorded planktonic and benthic organism blooms in the river groove shortly after the peak of the flood (Humphries et al., 1999). The importance of these organisms for the growth of fish larvae has been recognized by several authors (Cushing, 1990; Rossi, 2001), and has even been considered a reproductive trigger for some species of fish (Limburg et al., 1999).

According to the match-mismatch hypothesis, the highest survival rates during the first stages of the life cycle occur when the first larval feeding period happens when there is adequate food available in the environment (Cushing, 1990). No significant correlation was found between the densities of the zooplanktonic and ichthyoplanktonic organisms during the year studied; however, during the reproductive period (spring-summer) the peak of the zooplanktonic organisms in the environment (December) coincided with the peak in larva density.

This study allows us to conclude that the Ivinhema River is an important reproduction area for the fish of the upper Paraná River floodplain, including several migratory species. During the year studied, most species' reproductive period was well defined - occurring between the months of October and February - and coincided with the highest photoperiod values. Nevertheless, it was verified that the response of the reproductive intensity to the environmental variables varies from species to species.

\section{Acknowledgements}

The authors would like to thank Universidade Estadual de Maringá and Nupélia (Núcleo de Pesquisas em Limnologia, Ictiologia e Aquicultura) for the encouragement of research 
and for granting scientific initiation scholarship to college students; PELD/CNPq (Process $n^{\circ}$ 520.026/98-5) e CNPq (Process $n^{\circ} 476162 / 2004-1$ ) for making the project possible, our friends Alfredo Soares, Sebastião Rodrigues and Valmir Alves Teixeira and for their assistance with fieldwork and our friends from the Ichthyoplankton Laboratory (Nupélia/UEM) for helping in laboratory analyses.

\section{Literature Cited}

Agostinho, A. A., L. C. Gomes, S. Veríssimo \& E. K. Okada. 2004. Flood regime, dam regulation and fish in the Upper Paraná River: effects on assemblage attributes, reproduction and recruitment. Reviews in Fish Biology and Fisheries, 14: 1119.

Agostinho, A. A., H. F. Júlio Jr., L. C. Gomes, L. M. Bini \& C. S. Agostinho. 1997. Composição, abundância e distribuição espaço-temporal da ictiofauna. Pp. 179-208. In: Vazzoler, A. E. A. M., A. A. Agostinho \& N. S. Hahn (Eds.). A planície de inundação do alto rio Paraná: aspectos físicos, biológicos e socioeconômicos. Maringá, Eduem, 460p.

Agostinho, A. A. \& M. Zalewski. 1995. The dependence of fish community structure and dinamics on floodplain and riparian ecotone zone in Paraná River, Brazil. Hydrobiologia, 303: 141148.

Arumugan, P. T. \& M. C. Geddes. 1987. Feeding and growth of golden perch larvae and fry (Macquaria ambigua Richardson). Transactions of the Royal Society of South Australia, 111: 5965.

Baumgartner, G., K. Nakatani, M. Cavicchioli \& M. S. T. Baumgartner. 1997. Some aspects of the ecology of fish larvae in the floodplain of the high Paraná River, Brazil. Revista Brasileira de Zoologia, 14: 551-563.

Baumgartner, G., K. Nakatani, L. C. Gomes, A. Bialetzki, P. V. Sanches \& M. C. Makrakis. 2004. Identification of spawning sites and natural nurseries in the upper Paraná River, Brazil. Environmental Biology of Fishes, 71: 115-125.

Baumgartner, G., K. Nakatani, L. C. Gomes, A. Bialetzki, P. V. Sanches \& M. C. Makrakis. 2008. Fish larvae from the Upper Paraná River: Do abiotic factors affect larvala density? Neotropical Ichthyology, 6(4): 551-558.

Bialetzki, A., K. Nakatani, P. V. Sanches \& G. Baumgartner. 2004. Eggs and larvae of the "curvina" Plagioscion squamosissimus (Heckel, 1840) (Osteichthyes, Sciaenidae) in the Baía River, Mato Grosso do Sul State, Brazil. Journal of Plankton Research, 26: 1327-1336.

Bialetzki, A., K. Nakatani, P. V. Sanches, G. Baumgartner \& L. C. Gomes. 2005. Larval fish assemblage in the Baía River (Mato Grosso do Sul State, Brazil): temporal and spatial patterns. Environmental Biology of Fishes, 73: 37-47.

Bonetto, A. A., W. Dioni \& C. Pignalberi. 1969. Limnological investigations on biotic communities in the Middle Paraná River Valley. Verhandlungen der Internationalen Vereinigung Limnologie, 17: 1035-1050.

Cushing, D. H. 1990. Plankton production and year-class strength in fish populations: an update of the match/mismatch hypothesis. Advanced Marine Biology, 26: 249-292.

Hair, J. F, R. E. Anderson, L. Tatham \& B. J. Grablowski. 1984. Multivariate data analysis. McMillan, New York, 360p.

Harris, J. H. \& P. C. Gehrke. 1994. Larval feeding. Pp. 195-199. In: Hancok, D. A. (Ed.). Population dynamics for fisheries managements, editor Australian Society for Fish Biology Workshop Proceedings, Perth, 486p.

Hicks, C. R. 1993. Fundamental concepts in the design of experiments. Saunders College Publishing, New York, 509p.

Humphries, P., A. J. King \& J. D. Koehn. 1999. Fish, flows and flood plains: links between freshwater fishes and their environment in the Murray-Darling river system, Australia. Environmental Biology of Fishes, 56: 129-151.

Jackson, D. A. 1993. Stopping rules in principal components analysis: a comparison of heuristical and statistical approaches. Ecology, 74: 2204-2214.

King, A. J., P. Humphries \& P. S. Lake. 2003. Fish recruitment on floodplains: the roles of patterns of flooding and life history characteristics. Canadian Journal of Fisheries Aquatic Science, 60: 773-786.

Limburg, K. E., M. L. Pace \& K. K. Arend. 1999. Growth, mortality, and recruitment of larval (Morone spp.) in relation to food availability and temperature in the Hudson River. Fishery Bulletin US, 97: 80-91.

Lowe-McConnell, R. H. 1987. Ecological studies in tropical fish communities. Cambridge University Press, Cambridge, 382p.

Munro, A. D. 1990. General introduction. Pp. 1-11. In: Munro, A. D., A. P. Scott \& T. J. Lam (Eds.). Reproductive seasonality in teleosts: Environmental influences. CRC Press, Florida, 254p.

Nakatani, K., A. A. Agostinho, G. Baumgartner, A. Bialetzki, P. V. Sanches, M. C. Makrakis \& C. S. Pavanelli. 2001. Ovos e larvas de peixes de água doce: desenvolvimento e manual de identificação. Maringá, Eduem, 378p

Nakatani, K., G. Baumgartner \& M. Cavicchioli. 1997. Ecologia de ovos e larvas de peixes. Pp. 281-306. In: Vazzoler, A. E. A. M., A. A. Agostinho \& N. S. Hahn (Eds.). A planície de inundação do alto rio Paraná: aspectos físicos, biológicos e socioeconômicos. Maringá, Eduem, 460p.

Oldani, N. O. 1990. Variaciones de la abundancia de peces del valle del rio Paraná (Argentina). Revista de Hydrobiogia Tropical, 23: 67-76.

Peters, R. K. 1986. The role of prediction in limnology. Limnology and Oceanography, 31: 1143-1159.

Quiroz, R. \& S. Cutch. 1989. The fisheries and limnology of the lower Plata Basin. Pp. 123-129. In: Dodge, D. P. (Ed.). Proceedings of the international large rivers symposium. Canadian Journal of Fisheries Aquatic Science Special Publish 106: 429-443.

Reynalte-Tataje, D. A., S. Hermes-Silva, L. A. Weiss \& E. ZaniboniFilho. 2008. Distribuição e abundância temporal do ictioplâncton no alto rio Uruguai, Brasil. Pp. 195-228. In: Zaniboni-Filho, E. \& A. P. O. Nuñer. (Eds.). Reservatório de Itá. Estudos ambientais, desenvolvimento de tecnologias de cultivo e conservação da ictiofauna. Florianópolis, Editora UFSC, 319p.

Reynalte-Tataje, D. A. \& E. Zaniboni-Filho. 2008. Biologia e identificação de ovos e larvas de peixes do alto rio Uruguai, Brasil. Pp. 229-256. In: Zaniboni-Filho, E. \& A. P. O. Nuñer. (Eds.). Reservatório de Itá. Estudos ambientais, desenvolvimento de tecnologias de cultivo e conservação da ictiofauna. Florianópolis, Editora UFSC, 319p.

Rossi, L. M. 2001. Ontogenetic diet shifts in a neotropical catfish, Sorubim lima (Schneider) from the River Paraná System. Fisheries Management and Ecology, 8: 141-152.

Sanches, P. V., K. Nakatani, A. Bialetzki, G. Baumgartner, L. C. Gomes \& E. A. Luiz. 2006. Flow regulation by dams affecting ichthyoplankton: the case of the Porto Primavera Dam, Paraná River, Brazil. River Research and Applications, 22: 555-565. 
Sanders, H. L. 1960. Benthic studies in Buzzard Bay. III. The structure of the soft-bottom community. Limnology and Oceanography, 5: 138-153.

Souza Filho, E. E. \& J. C. Stevaux. 1997. Geologia e Geomorfologia do complexo rio Baia, Curutuba, Ivinhema. Pp. 3-46. In: Vazzoler, A. E. A. M., A. A. Agostinho \& N. S. Hahn (Eds.). A planície de inundação do alto rio Paraná: aspectos físicos, biológicos e socioeconômicos. Maringá, Eduem, 460p.

Stanford, J. A., J. V. Ward \& W. J. Liss. 1996. A general protocol for restoration of regulated rivers. Regulated Rivers, 12: 391-501.

Suzuki, H. I., C. K. Bulla \& A. A. Agostinho. 2005. Estratégias reprodutivas de assembléias de peixes em reservatórios. Pp. 223-236. In: Rodrigues, L., S. M. Thomaz \& A. A. Agostinho. (Eds.). Biocenoses em reservatórios. Padrões espaciais e temporais. São Carlos, RiMa, 320p.

Thomaz, S. M., L. M. Bini \& R. L. Bozelli. 2007. Floods increase similarity among aquatic habitats in river-floodplain systems. Hydrobiologia, 519: 1-13

Vazzoler, A. E. A. M. 1996. Biologia da reprodução de peixes teleósteos: teoria e prática. Maringá, Eduem, 169p.

Vazzoler, A. E. A. M., M. A. P. Lizama \& P. Inada. 1997. Influências ambientais sobre a sazonalidade reprodutiva. Pp. 267-280. In: Vazzoler, A. E. A. M., A. A. Agostinho \& Hahn, N. S. (Eds.). A planície de inundação do alto rio Paraná: aspectos físicos, biológicos e socioeconômicos. Maringá, Eduem, 460p.

Vlaming, V. L. 1972. Environmental control of teleost reproductive cycles: a brief review. Journal of Fish Biology, 4: 131-140.

Ward, J. V. \& J. A. Stanford. 1989. Riverine ecosystems: the influence of man on catchment dynamics and fish ecology. In: Dodge, D. P. (Ed.). Proceedings of the International Large Rivers Symposium, vol 106; Canadian Special Publication of Fiheries and Aquatic Sciences, 335p.

Winemiller, K. O. 2004. Floodplain river food webs: generalizations and implications for fisheries management. Pp. 285-309. In: Welcomme, R. L. \& T. Petr. (Eds.). Proceedings of the Second International Symposium on the Management of Large Rivers for Fisheries FAO Publication, Bangkok, 487p.

Accepted February 14, 2011

Published June 30, 2011 